\title{
Tangential flow diafiltration: an improved technique for estimation of virioplankton production
}

\author{
Danielle M. Winget ${ }^{1}$, Kurt E. Williamson ${ }^{2}$, Rebekah R. Helton ${ }^{2}$, K. Eric Wommack ${ }^{1,2, *}$ \\ ${ }^{1}$ College of Marine Studies, and ${ }^{2}$ Department of Plant and Soil Sciences, Delaware Biotechnology Institute, \\ University of Delaware, 15 Innovation Way, Newark, Delaware 19711, USA
}

\begin{abstract}
Accurate estimates of viral production in natural environments are critical for assessing the impacts of viral lysis on bacterial mortality and dissolved organic matter release. Here, viral production was estimated using a tangential flow diafiltration (TFD) dilution method, which reduced viral abundance to about $25 \%$ of ambient while maintaining near ambient levels of bacterial abundance. In subsequent incubations, the rate of virus-like particle increase was measured and used to calculate viral production. TFD viral production estimates were compared to those from simultaneous incubations using a vacuum diafiltration procedure. At 4 stations in the Chesapeake and Delaware Bays, viral production averaged $4.8 \pm 1.7 \times 10^{10}$ and $5.9 \pm 4.4 \times 10^{10}$ viruses $\mathrm{l}^{-1} \mathrm{~d}^{-1}$ as assessed by the TFD and vacuum methods, respectively. The TFD procedure improved upon the vacuum-based method by recovering significantly more of the bacterial community and requiring less sample processing time. Optimization tests of the TFD procedure found that a $0.22 \mu \mathrm{m}$ pore size filter with a

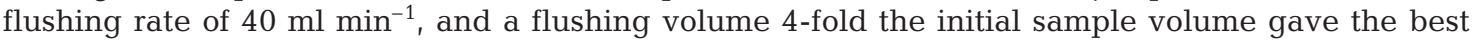
combination of bacterial recovery, viral dilution, and processing time. Based on TFD viral production estimates, viral lysis was responsible for the loss of 14 to $93 \%$ of the bacterial standing stock and the release of 22 to $47 \mu \mathrm{g} \mathrm{Cl}^{-1} \mathrm{~d}^{-1}$ in the Chesapeake and Delaware Bays. These results indicate that viral lysis is a significant factor for microbial mortality and dissolved organic matter cycling within these estuaries.
\end{abstract}

KEY WORDS: Viral production · Tangential flow diafiltration · Viral-mediated mortality · Dilution method Resale or republication not permitted without written consent of the publisher

\section{INTRODUCTION}

Marine viruses were initially discovered to be highly abundant members of the marine environment about 15 yr ago (Bergh et al. 1989). Since then, many studies have focused on marine cyanophage host specificity (Suttle \& Chan 1993, Waterbury \& Valois 1993, Lu et al. 2001), viral diversity (Cottrell \& Suttle 1991, Wommack et al. 1999, Wang \& Chen 2004), and the potential impacts of viral infection on phyto- and bacterioplankton community composition (Thingstad \& Lignell 1997, van Hannen et al. 1999, Fuhrman \& Schwalbach 2003, Winter et al. 2004b). By comparison, fewer investigations on the potential influence of viruses and viral infection on the cycling of dissolved organic matter (DOM) through the marine food web have been con- ducted. In addition to causing bacterial and phytoplankton death, viral lysis diverts microbial cell biomass into the DOM pool and away from higher trophic levels (Proctor \& Fuhrman 1991, Bratbak et al. 1992, Fuhrman 1992, 1999, Wilhelm \& Suttle 1999, Wommack $\&$ Colwell 2000). Accurate estimates of in situ viral production are critical for quantifying the effects of viral lysis on DOM cycling and host population mortality.

Viral production (VP), the amount of viruses produced within a given time period and volume, can be inferred from the rate of increase in viral abundance over time. Using an assumed or average burst size for a typical viral infection, VP rates can be used to calculate viral-mediated bacterioplankton lysis, i.e. viral-mediated mortality (VMM) (Steward et al. 1996, Noble \& Fuhrman 2000, Wilhelm et al. 2002), and to estimate the 
amount of $\mathrm{C}, \mathrm{N}$, and $\mathrm{P}$ released into a system by viral cell lysis (Fuhrman 1992, Steward et al. 1996, Gobler et al. 1997, Weinbauer \& Höfle 1998, Wilhelm et al. 2002). Approaches to estimation of VP have been numerous and include electron microscopic observation of the frequency of visibly infected cells (FVIC) (Proctor et al. 1993, Steward et al. 1996, Binder 1999, Guixa-Boixereu et al. 1999, Hwang \& Cho 2002, Middelboe et al. 2002, Choi et al. 2003, Weinbauer et al. 2003a), contact rates of viruses and bacteria (Murray \& Jackson 1992, Suttle \& Chan 1994), incorporation of ${ }^{3} \mathrm{H}$-thymidine or ${ }^{32} \mathrm{P}$ into viral DNA (Steward et al. 1992a, 1996, Fuhrman \& Noble 1995, Kepner et al. 1998), viral decay rates (Heldal \& Bratbak 1991, Bratbak et al. 1992, Guixa-Boixereu et al. 1999, Tuomi \& Kuuppo 1999), fluorescently labeled viruses (FLVs) as tracers of viral decay and VP (Noble \& Fuhrman 2000, Helton et al. 2005, this issue), and dilution methods (Wilhelm et al. 2002, Winter et al. 2004a, Helton et al. 2005). The assumptions, advantages, and disadvantages of each of these approaches to measuring VP are summarized in Table 1. For many of these methods, 1 or more of the assumptions or conversion factors upon which the assessment of VP is based remains untested or poorly constrained.

Recently, Wilhelm et al. (2002) introduced a dilution approach in which vacuum filtration through a $0.22 \mu \mathrm{m}$ impact filter reduced viral abundance prior to incuba-

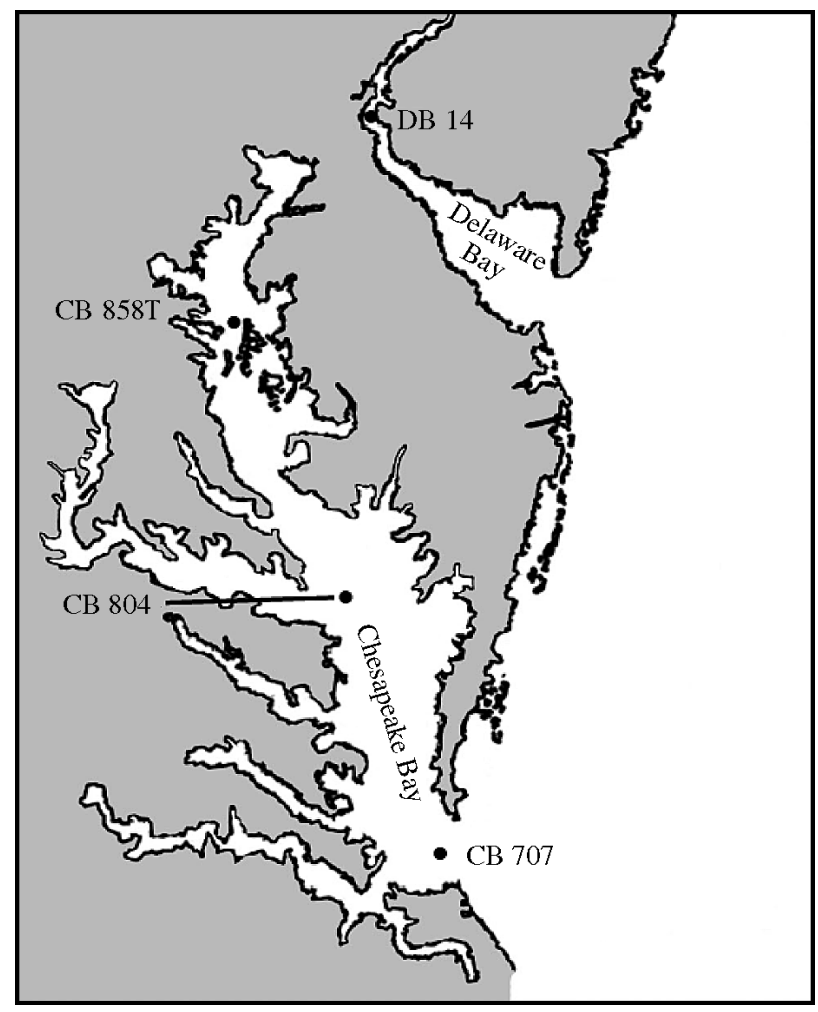

Fig. 1. Diagram of sampling station locations in the Chesapeake and Delaware Bays tion. This method allows for direct observation of VP from a natural microbial consortia and requires only 1 correction factor, the reciprocal of the percent loss of bacteria, to estimate VP (Weinbauer et al. 2002, Wilhelm et al. 2002, Poorvin et al. 2004). Thus, it bypasses many of the assumptions and conversion factors necessary for other VP techniques. Removal of viruses by dilution prior to incubation lowers the occurrence of new viral infections during incubation and reduces the background level of viruses to ease enumeration throughout the experiment. However, a critical limitation to dilution-based estimates of VP is the loss of bacteria during filtration. In our experience, $>80 \%$ of bacteria are typically lost during vacuum diafiltration using $0.22 \mu \mathrm{m}$ impact filters. To improve bacterial recovery and viral dilution, a new technique employing tangential flow diafiltration was developed and tested using water samples from the Chesapeake and Delaware Bays. Loss of viruses, recovery of bacteria, and estimates of VP obtained from both vacuum and tangential flow diafiltration methods (Wilhelm et al. 2002) were compared.

\section{MATERIALS AND METHODS}

Sampling. Water samples for VP experiments were collected along the main stem and tributaries of the Chesapeake Bay at Stns CB 858T, CB 804 and CB 707 (Fig. 1) in August and September 2002; March, April, June, July, and August 2003; and July 2004. Samples were also gathered in the Delaware Bay at Stn DB 14 during August 2002. For all samples, surface water from approximately $1 \mathrm{~m}$ depth was collected in $10 \mathrm{l}$ Niskin bottles using a CTD (Seabird 911 Plus) and then transferred to a 1 or 21 acid-cleaned and triple-rinsed polycarbonate bottle. Sub-samples of 5 or $15 \mathrm{ml}$ of ambient water were collected, preserved with addition of formalin to a final concentration of $1 \%$, and stored at $4^{\circ} \mathrm{C}$ on the August 2002, September 2002, and March 2003 cruises until analysis for viral and bacterial abundance via epifluorescence microscopy. All other water samples were frozen in liquid nitrogen within $12 \mathrm{~h}$ of collection and stored at $-70^{\circ} \mathrm{C}$. The remaining ambient water was filtered through $50 \mu \mathrm{m}$ Spectra mesh and kept in the dark at ambient water temperature in an on-board flow table until diafiltration (1 to $2 \mathrm{~h}$ ).

The rate of VP in water samples was assumed to be equal to the rate of appearance of new viral particles after removal of the majority of the natural viral community via dilution with virus-free seawater (Wilhelm et al. 2002). Two methods of viral removal were performed in this study.

Vacuum diafiltration. The first closely followed the dilution procedure reported by Wilhelm et al. (2002). 


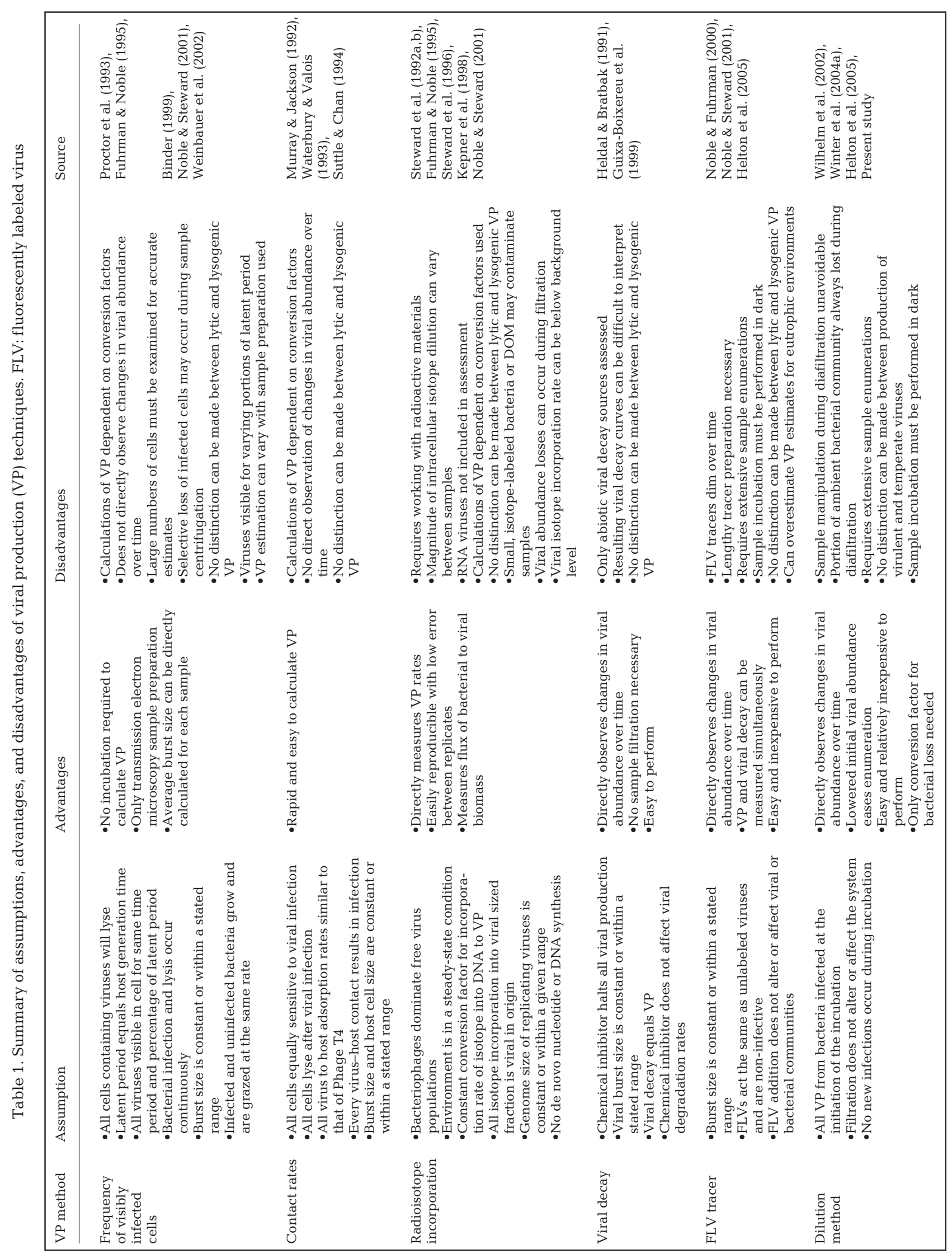


Briefly, $300 \mathrm{ml}$ water samples were vacuum filtered through a $47 \mathrm{~mm}, 0.2 \mu \mathrm{m}$ pore size Supor 200 filter (Pall Corporation). Continuous flushing with a $25 \mathrm{ml}$ transfer pipette was employed to keep bacteria suspended in the filter reservoir during diafiltration (Weinbauer et al. 2002). As seawater was removed via filtration, virus-free seawater (30 $\mathrm{kDa}$ filtered) from the same location was added to the filter reservoir until 3 vol (900 ml total) had been flushed through the filter. This flushing volume was expected to remove about $90 \%$ of the ambient viral population. After completion of diafiltration, $100 \mathrm{ml}$ of the remaining viral-reduced water sample was immediately aliquoted into each of 3 polycarbonate bottles $(250 \mathrm{ml})$ and incubated in the dark at in situ temperatures in an on-board flow table. Immediately after aliquoting, 5 or $10 \mathrm{ml}$ sub-samples ( $t_{0}$ samples) of each of the 3 replicates were taken, preserved, and stored as above. Sub-sampling was repeated at $3 \mathrm{~h}$ intervals for $12 \mathrm{~h}$. Samples from this method are hereafter referred to as 'vacuum' samples.

Tangential flow diafiltration. The second method of viral removal employed tangential flow diafiltration (TFD) instead of vacuum diafiltration. In the TFD method, water is drawn into the feed line using a peristaltic pump, flows over a $0.22 \mu \mathrm{m}$ pore size filter (PelliconXL, Millipore), and out the retentate line (Fig. 2). Reducing the diameter of the retentate line with a clamp creates back pressure inside the filter cartridge and forces water and particles smaller than the filter's pore size through the filter and out the permeate line. A similar procedure, using 30 to $100 \mathrm{kDa}$ filters, is routinely employed for collection and concentration of viruses from ambient water samples (Chen et al. 1996, Wommack et al. 1999, Wang \& Chen 2004, Winter et al. $2004 \mathrm{~b})$. Throughout the process, the retentate line is directed into the sample container to return particles $>0.22 \mu \mathrm{m}$ (i.e. bacteria) to the sample. As in vacuum diafiltration, $300 \mathrm{ml}$ of $50 \mu \mathrm{m}$ pre-filtered water was poured into a $500 \mathrm{ml}$ square polycarbonate bottle. After the feed line was primed with a peristaltic pump, the combined permeate plus retentate flow rate was adjusted to $40 \pm 2 \mathrm{ml} \mathrm{min}^{-1}$ with a back pressure of 8 to 10 psi by changing the pump speed and retentate line diameter. The permeate line was then removed from the sample bottle to filter out water and particles $<0.22 \mu \mathrm{m}$ in size from the sample. Permeate volume was replaced by the addition of virus-free, ultra-filtered seawater to the sample. Three vol (900 ml total) of virus-free seawater were used for diafiltration in all experiments except as noted for specific optimization experiments. After completion of viral dilution, the filter was back-flushed according to manufacturer recommendations to recover water remaining in the filter. The viral-reduced sample was aliquoted, incubated, and sub-sampled as described previously for the vac-

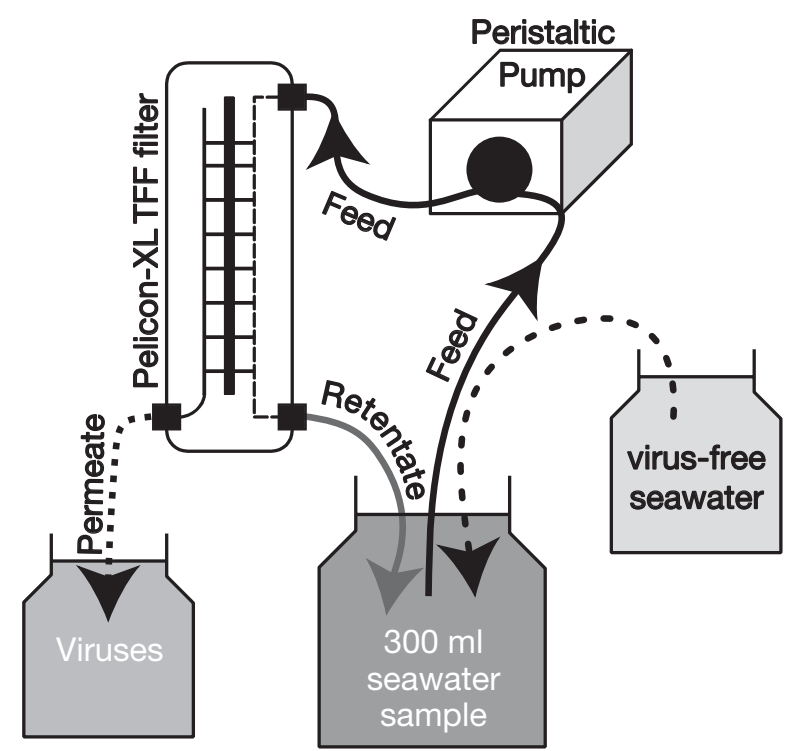

Fig. 2. Tangential flow diafiltration (TFD) procedure. Sample water is pumped through the feed line (solid arrow) into the TFD filter using a peristaltic pump. As the water passes through the $0.22 \mu \mathrm{m}$ filter, back pressure forces viruses and seawater through the filter into the permeate (dotted arrow). Remaining water and bacteria flow back into the sample container through the retentate line (gray arrow). The volume of water lost through the permeate is replaced by the addition of virus-free water (dashed arrow)

uum diafiltration method. Samples from this method are hereafter referred to as 'TFD' samples.

TFD method optimizations. To determine the effects of dilution volume and flow rate on bacterial recovery and viral loss, a $0.22 \mu \mathrm{m}$ pore size TFD filter was assessed at 3-fold (900 ml) and 4-fold (1200 ml) flushing volumes at each of 3 flow rates - low $\left(30 \mathrm{ml} \mathrm{min}^{-1}\right)$, medium (40 $\mathrm{ml} \mathrm{min}^{-1}$ ), and high (50 $\mathrm{ml} \mathrm{min}^{-1}$ ). A $0.45 \mu \mathrm{m}$ pore size filter was subjected to the same set of conditions to determine the effects of filter pore size on bacterial recovery and viral loss. Samples of 5 to $10 \mathrm{ml}$ of ambient water were collected prior to and immediately after dilution was completed and were stored as described above. Each set of conditions was replicated twice at different stations and on different sampling dates. The results of the 2 experiments were averaged to determine which combination of factors produced the greatest bacterial recovery and viral dilution.

Viral and bacterial abundance. In all samples, viral and bacterial abundances were assessed via epifluorescence microscopy after staining with SYBR Gold (Chen et al. 2001). Briefly, 0.5 to $3 \mathrm{ml}$ of sample was filtered onto a $25 \mathrm{~mm}, 0.02 \mu \mathrm{m}$ Anodisc filter (Whatman) supported by a $0.2 \mu \mathrm{m}$ Supor filter (Pall Corp.) and an extra thick glass fiber filter (Pall Corp.) and stained with $2.5 \times$ SYBR Gold for $15 \mathrm{~min}$ in the dark. Anodisc filters were then mounted onto glass slides using 
immersion oil and topped with an anti-fade solution (50\% glycerol, 50\% PBS, $0.1 \%$ anti-fade solution; Noble \& Fuhrman 1998) and an $18 \mathrm{~mm}$ round coverslip. For each filter, at least 200 virus-like particles (VLPs) and 10 microscopic fields were viewed under FITC excitation at $1000 \times$ magnification on a Zeiss Axioskop 2 (100× Plan-NEOFLUAR oil objective). Twelve-bit TIFF digital images of each field were captured using an ORCA-ER (Hamamatsu) camera. VLPs and bacteria were differentiated based on differences in size and fluorescence intensity. Both were enumerated from the digital images using FoVeaPro (Reindeer Software) plug-ins for Adobe Photoshop (Helton et al. 2005). For Stns DB 14 and CB 858T (August 2002) 0, 6, and $12 \mathrm{~h}$ sub-samples were analyzed within $12 \mathrm{~d}$ of sample collection, while the 3 and $9 \mathrm{~h}$ sub-samples were enumerated after 121 d. Stn CB 707 and CB 804 experiments (March 2003) were entirely enumerated within $25 \mathrm{~d}$ of collection.

Calculations of viral production and statistical analyses. For both the vacuum and TFD methods, the same calculations were used for bacterial recovery, viral loss, and VP. Bacterial recovery efficiency was calculated as the bacterial abundance at initiation of the experimental incubation divided by the bacterial abundance in ambient water, multiplied by 100 (Wilhelm et al. 2002). Similarly, percent viral loss or dilution, $L$, was calculated as:

$$
L=\left[1-\left(V_{t_{0}} / V_{\mathrm{a}}\right)\right] \times 100
$$

where $V_{t_{0}}$ is viral abundance at the initiation of the experimental incubation, and $V_{\mathrm{a}}$ is viral abundance in ambient water. VP was estimated from the slope of a first-order regression line of viral abundance versus incubation time (Wilhelm et al. 2002). The slopes of the 3 replicates were averaged and corrected for bacterial loss by multiplying by the ratio of bacterial abundance in ambient water to bacterial abundance in experimental incubations at the initiation of the experiment $\left(t_{0}\right)$. VMM was calculated as the VP estimate divided by the burst size, assumed to be 50 as in Wilhelm et al. (2002).
The percentage of bacterial production (BP) consumed by viral lysis was computed as the BP in cells $\mathrm{l}^{-1} \mathrm{~d}^{-1}$ divided by VMM. All BP rates were assessed using a modified ${ }^{3} \mathrm{H}$-leucine incorporation method (Kirchman et al. 1985, Smith \& Azam 1992). The percentage of bacterial standing stock lysed per day was calculated as VMM divided by ambient bacterial abundance.

All linear regressions were performed using Prism version 4.0 (Software Mackiev). Student's $t$-tests were employed to assess differences in bacterial recovery, viral dilution, and VP rates between the vacuum and TFD diafiltration methods and significant differences between ambient and initial abundances of bacteria and viruses. Multi-way and 1-way ANOVAs were performed to detect significant differences in bacterial recovery and viral dilution among the various optimization parameters tested. Tukey's post hoc tests were used to identify exact relationships when significant differences were found. The significance level for all tests was set at $\mathrm{p}<0.05$, and all statistical tests were performed using SPSS 11 software (SPSS).

\section{RESULTS}

\section{Dilution method comparisons}

At 2 stations in August 2002 and 2 stations in March 2003, the vacuum and TFD methods for VP were performed simultaneously. Although each diafiltration was started simultaneously, completion of the vacuum technique took about $1 \mathrm{~h}$ longer than the $90 \mathrm{~min}$ needed for completion of TFD. As a result, TFD incubations started and ended approximately $1 \mathrm{~h}$ earlier than the vacuum incubations. No significant differences were found in either viral or bacterial abundance after $50 \mu \mathrm{m}$ pre-filtration (data not shown). Bacterial abundances in estuarine water samples ranged from $2.2 \times 10^{9}$ to $1.0 \times 10^{10}$ cells $1^{-1}$ (Table 2). Bacterial recovery using vacuum diafiltration averaged $15 \%$ of ambient bacterial abundance and ranged from 7 to

Table 2. Bacterial abundance, viral production (VP), and recovery efficiencies. All numbers are mean \pm SE. ${ }^{*}$ Significant differences between tangential flow diafiltration (TFD) and vacuum methods. Student's $t$-test, $\mathrm{p}<0.05$

\begin{tabular}{|lcccccc|}
\hline Stn & Date & $\begin{array}{c}\text { Ambient bacterial } \\
\text { abundance }\left(\text { bacteria } \mathrm{l}^{-1}\right)\end{array}$ & Method & $\begin{array}{c}\text { VP } \\
\left(10^{10} \text { viruses }\right. \\
\left.\mathrm{l}^{-1} \mathrm{~d}^{-1}\right)\end{array}$ & $\begin{array}{c}\text { Ambient bacteria } \\
\text { recovered } \\
(\%)\end{array}$ & $\begin{array}{c}\text { Ambient viruses } \\
\text { removed } \\
(\%)\end{array}$ \\
\hline CB 858T & Aug 2002 & \multirow{2}{*}{$1.0 \times 10^{10}$} & Vacuum & $6.7 \pm 6.8$ & $25 \pm 1.7^{*}$ & $62 \pm 11$ \\
& & & TFD & $6.6 \pm 0.85$ & $68 \pm 1.6^{*}$ & $57 \pm 6.2$ \\
DB 14 & Aug 2002 & $4.3 \times 10^{9}$ & Vacuum & $-3.9 \pm 1.6$ & $19 \pm 2.6^{*}$ & $74 \pm 2.5$ \\
& & & TFD & $4.7 \pm 2.8$ & $53 \pm 4.6^{*}$ & $79 \pm 3.5$ \\
CB 707 & Mar 2003 & $2.3 \times 10^{9}$ & Vacuum & $25 \pm 10$ & $9.8 \pm 4.0^{*}$ & $92 \pm 2.2$ \\
& & & TFD & $-2.2 \pm 1.2$ & $32 \pm 3.2^{*}$ & $84 \pm 0.53$ \\
CB 804 & Mar 2003 & $2.2 \times 10^{9}$ & Vacuum & $-3.7 \pm 1.8^{*}$ & $6.5 \pm 1.2^{*}$ & $97 \pm 0.20^{*}$ \\
& & & TFD & $10 \pm 3.5^{*}$ & $66 \pm 9.6^{*}$ & $73 \pm 5.6^{*}$ \\
\hline
\end{tabular}


$25 \%$. For the TFD method, bacterial recovery averaged $55 \%$ and varied from 32 to $68 \%$ (Table 2). For all sampling stations, bacterial recovery efficiency by the TFD method was significantly higher than that of the vacuum procedure $(p<0.05)$. Bacterial abundances at the initiation of TFD experimental incubations were always significantly higher than those of vacuum incubations (Fig. 3, p < 0.05). At 3 of the 4 stations, the loss of bacteria using both methods was significant (Fig. 3, $\mathrm{p}<0.05$ ). At the fourth station (CB 804), ambient and initial incubation bacterial abundances were statistically identical using the TFD method, whereas ambient bacterial abundance exceeded initial incubation abundance using the vacuum method $(\mathrm{p}<0.05)$.

Vacuum diafiltration removed an average of $83 \%$ of ambient viruses and ranged from 62 to $97 \%$ viral dilution efficiency. TFD removed an average of $75 \%$ of ambient viruses and varied from 57 to $84 \%$ viral dilution efficiency. Despite the lower average viral loss rate of TFD, at only Stn CB 804 did vacuum diafiltration remove a greater percentage of ambient viruses than TFD (Table 2, p < 0.05).

VP estimates based on the entire $12 \mathrm{~h}$ incubation for both TFD and vacuum methods ranged from a net loss of viruses (e.g. $-3.7 \times 10^{10}$ viruses $\mathrm{l}^{-1} \mathrm{~d}^{-1}$ at Stn CB 804) to a high VP estimate of $25 \times 10^{10}$ viruses $\mathrm{l}^{-1} \mathrm{~d}^{-1}$ at Stn CB 707 (Table 2). In experiments conducted at Stns DB 14, CB 707, and CB 804 a net loss of viruses was recorded from one of the incubation methods, leading to a significant or nearly significant difference in resulting VP estimates from the 2 methods (DB 14: $p=0.055 ; C B$ 804: $p=0.026 ; C B 707: p=0.059$ ). For the station where both methods yielded a positive VP estimate, mean values were not significantly different

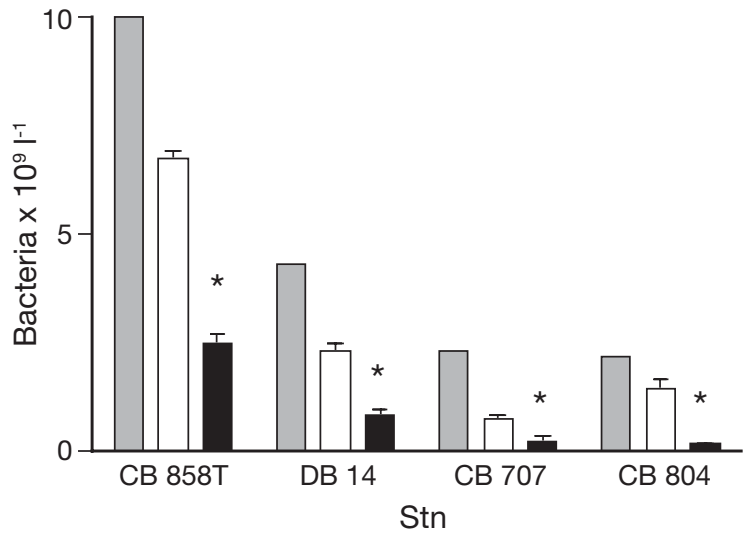

Fig. 3. Comparison of TFD and vacuum diafiltration methods. Bacterial abundance per liter in ambient water samples and water samples taken immediately after manipulation by either the TFD or vacuum dilution method (grey bars: ambient water; open bars: TFD method; black bars: vacuum method counts; *: significant differences between TFD and vacuum methods; error bars: $+\mathrm{SE}$ )
(CB 858T: $\mathrm{p}=0.995)$. Comparisons of VP estimates performed prior to correction for bacterial recovery efficiency indicated that the TFD and vacuum-based VP methods differed significantly at Stns CB 707 and CB 804 (Fig. 4a, p < 0.05). No significant correlation or regression was found between VP estimates and either the percentage of ambient bacteria recovered or the percentage of ambient viruses removed (data not shown). Correlation and regression analysis of VP estimates and ambient or $t_{0}$ bacterial and viral abundances or virus to bacteria ratios (VBR) were not significant either (data not shown).

\section{TFD method optimizations}

To determine the optimal conditions for TFD, combinations of 3 different flow rates (low, medium, and high), 2 filter sizes $(0.22$ and $0.45 \mu \mathrm{m})$, and 2 flushing volumes of virus-free seawater (3- and 4-fold sample
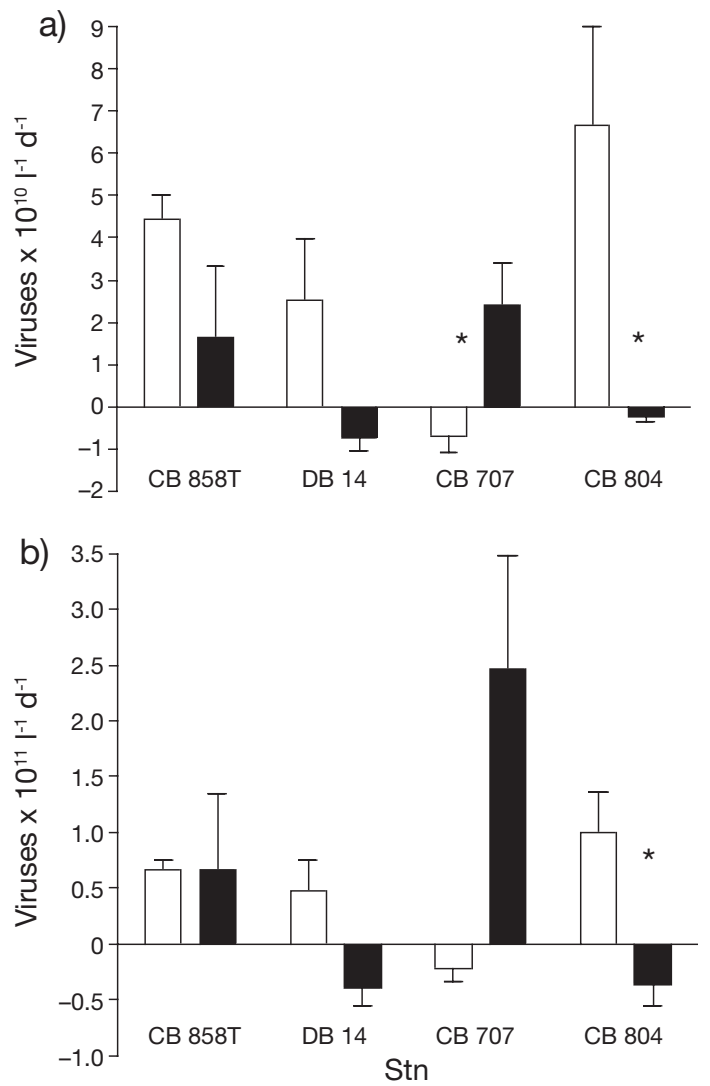

Fig. 4. Comparison of average viral production estimates between TFD and vacuum diafiltration methods. Viral production estimates (a) prior to correction for bacterial recovery efficiency and (b) after correction for bacterial recovery efficiency (open bars: TFD-based viral production estimates; black bars: vacuum-based viral production estimates; *: significant differences between estimates; error bars: +SE) 


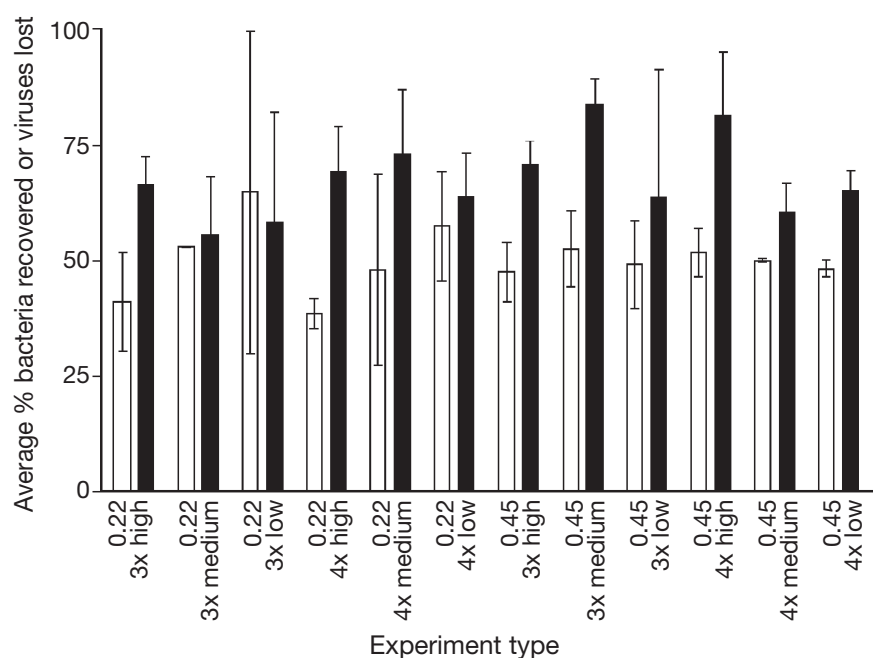

Fig. 5. Comparison of the percentages of ambient bacteria recovered and ambient viruses diluted out by various TFD method conditions ( 0.22 : use of a $0.22 \mu \mathrm{m}$ pore size TFD filter; 0.45: use of a $0.45 \mu \mathrm{m}$ pore size TFD filter; $3 \times$ and $4 \times$ : $3-$ and 4 -fold, respectively, of the original sample volume of virusfree water used to replace water lost to permeate; high: a flow rate of $50 \mathrm{ml} \mathrm{min}^{-1}$; medium: $40 \mathrm{ml} \mathrm{min}^{-1}$; low: $30 \mathrm{ml} \mathrm{min}^{-1}$; open bars: \% of ambient bacteria recovered; black bars: \% of ambient viruses diluted out by diafiltration; error bars: $\pm \mathrm{SE}$ )

volume) were tested on water samples collected from March 2003 through July 2004 (Fig. 5). Replicates of experimental conditions were performed at different stations on separate cruises to account for effects of changing environmental conditions such as increased turbidity. None of the parameters tested had a significant effect on either bacterial recovery or viral loss efficiency $(p>0.05)$. Average viral loss and bacterial recovery rates were similar for the 0.45 and $0.22 \mu \mathrm{m}$ pore size filters: $71 \%$ viral loss, $50 \%$ bacterial recovery and $68 \%$ viral loss, $44 \%$ bacterial recovery, respectively.

Average bacterial recovery and viral loss rates for the 3- and 4-fold flushing volumes were as follows: $45 \%$ bacterial recovery, $70 \%$ viral loss and $49 \%$ bacterial recovery, $69 \%$ viral loss, respectively. In 25 subsequent experiments, the 4 -fold flushing volume averaged $68 \%$ viral dilution and $55 \%$ bacterial recovery (data not shown). The low flow rate of $30 \mathrm{ml} \mathrm{min}{ }^{-1}$ required $45 \mathrm{~min}$ longer to complete than the other flow rates and averaged $46 \%$ bacterial recovery and $68 \%$ viral loss. The highest flow rate of $50 \mathrm{ml} \mathrm{min}{ }^{-1}$ had the lowest average bacterial recovery efficiency at $45 \%$, but the highest mean viral dilution at $72 \%$. The medium flow rate of

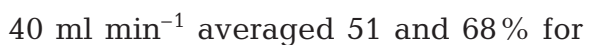
bacterial recovery and viral dilution rates, respectively.
Examination of TFD VP experiments revealed internal fluctuations of VP at various time points. For instance, an increasing rate of VP followed by a decreasing rate was seen at $3 \mathrm{~h}$ intervals at Stn CB 858T. These variations resulted in different VP estimates based on the end time point chosen for the regression (data not shown). However, the VP estimate significantly varied with the time interval $(6,9$, or $12 \mathrm{~h})$ used in the calculation only at Stn CB 858T ( $<<0.05)$.

\section{Biogeochemical impacts of viral lysis}

From TFD-based VP estimates, several biologically important parameters were calculated for each station (Table 3). Because experiments that indicate a net loss of viruses (negative VP rate) are counter-intuitive when applied to calculations of viral-mediated bacterial mortality, the experiment conducted at Stn CB 707 was excluded from further analyses. VMM ranged from a low of $9.4 \times 10^{8}$ to a high of $2.0 \times 10^{9}{\text { bacteria } \mathrm{l}^{-1}}^{-1}$ $\mathrm{d}^{-1}$. The percentage of BP lost to viral lysis (84 to $207 \%$ ) was generally higher in the late summer, and corresponded to a loss of between 14 and $93 \%$ of the bacterial standing stock $\mathrm{d}^{-1}$. Assuming that $23.3 \mathrm{fg} \mathrm{C}$ per bacterial cell is released into the DOM pool upon cell lysis (Wilhelm et al. 1998, 2002), the amount of carbon released based on TFD VP estimates varied from 22 to $47 \mu \mathrm{g} \mathrm{C}^{-1} \mathrm{~d}^{-1}$ (Table 3). Carbon release calculated for Stn CB 804 in March was almost double the average $\mathrm{C}$ release for the August stations.

\section{DISCUSSION}

\section{Assessment of TFD method}

Termed the 'viral-shunt' (Wilhelm \& Suttle 1999), the loss of microbial biomass to viral lysis is among the most poorly understood processes within the microbial loop (Wilhelm \& Suttle 1999, Wommack \& Colwell 2000). Accurate determination of viral-mediated
Table 3. Viral and bacterial parameters calculated from viral production (VP) estimates. VMM: virally mediated mortality, VP/burst size of $50 ; \%$ bacterial production (BP) consumed by viral lysis: BP/VMM; viral turnover time: VP/viral abundance $\times 24 \mathrm{~h} \mathrm{~d}^{-1}$; carbon released: VMM $\times 23.3 \mathrm{fg} \mathrm{C}$ bacteria $^{-1}\left(1 \times 10^{-9}\right)$

\begin{tabular}{|lccccc|}
\hline Stn & Date & $\begin{array}{c}\text { VMM } \\
\left(10^{9} \text { bacteria }\right. \\
\left.\mathrm{l}^{-1} \mathrm{~d}^{-1}\right)\end{array}$ & $\begin{array}{c}\text { BP } \\
\text { consumed by } \\
\text { viral lysis }(\%)\end{array}$ & $\begin{array}{c}\text { Viral } \\
\text { turnover } \\
\text { time }\left(\mathrm{d}^{-1}\right)\end{array}$ & $\begin{array}{c}\text { Carbon } \\
\text { released } \\
\left(\mu \mathrm{C} \mathrm{C}^{-1} \mathrm{~d}^{-1}\right)\end{array}$ \\
\hline CB 858T & Aug 2002 & 1.5 & 207 & 1.1 & 34 \\
DB 14 & Aug 2002 & 0.9 & 105 & 0.51 & 22 \\
CB 804 & Mar 2003 & 2.0 & 84 & 0.49 & 47 \\
\hline
\end{tabular}




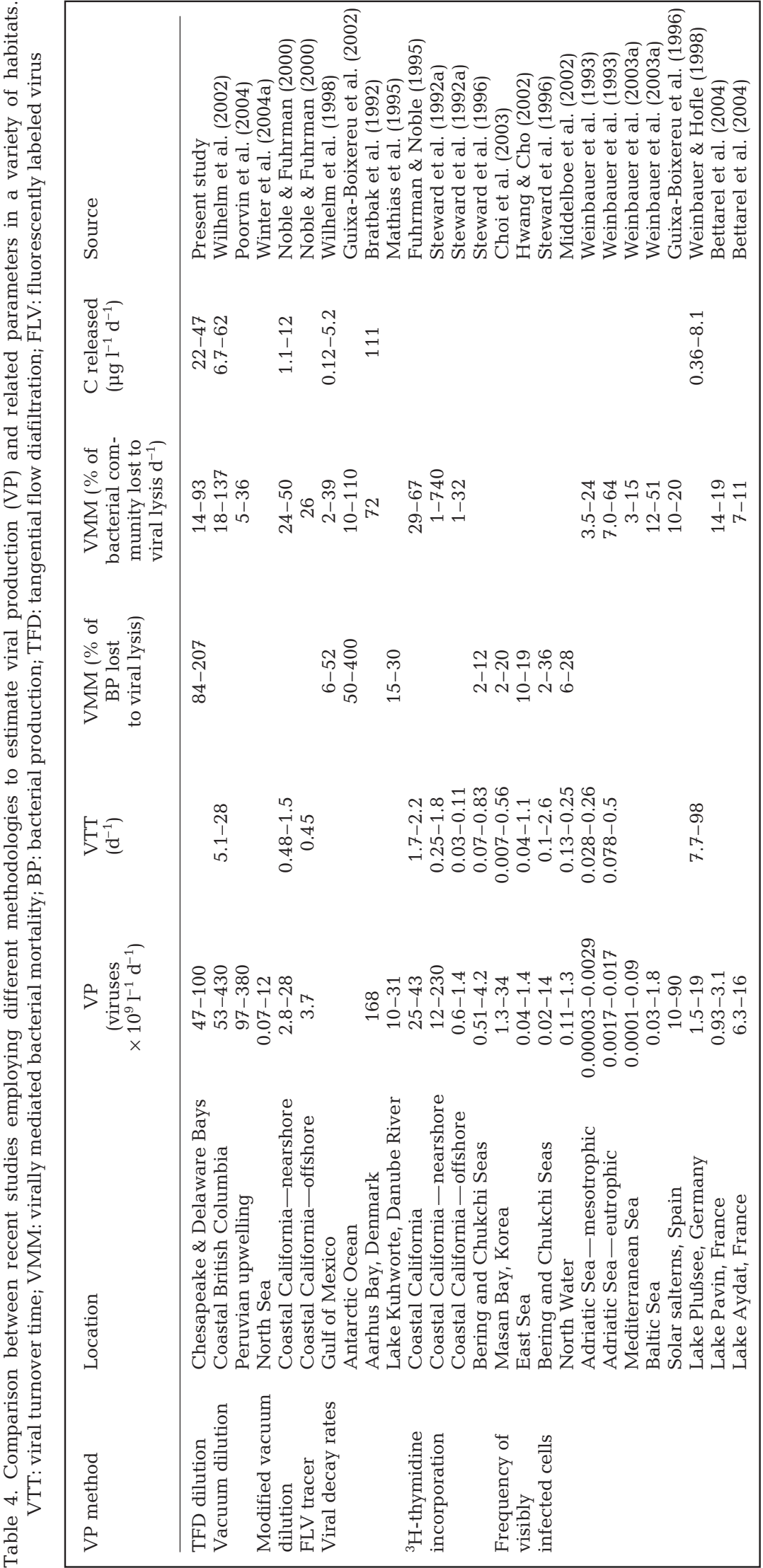

bacterioplankton mortality is critical for constraining the flux of $\mathrm{C}$ through the viral-shunt and relies on 2 key estimates: average burst size and VP rate. Reported calculations of VMM have used either an assumed average burst size or direct observation of the average number of viruses within infected cells through electron microscopy (Weinbauer et al. 1993, Winter et al. 2004a). An assumed burst size of 50 viruses per burst has been used in several studies (Heldal \& Bratbak 1991, Steward et al. 1996, Tuomi \& Kuuppo 1999, Noble \& Fuhrman 2000, Wilhelm et al. 2002). Based on the large variability inherent to burst size estimates from electron microscopy (Steward et al. 1996, Noble \& Steward 2001), and the larger burst sizes observed in locations with higher bacterial activity (Weinbauer \& Peduzzi 1995, Bettarel et al. 2004, Winter et al. 2004a), such as the Chesapeake and Delaware Bays, we felt the choice of an assumed burst size of 50 was also valid and appropriate for the estuarine waters studied here.

Dilution-based VP estimates for Chesapeake and Delaware Bays varied from $-2.2 \pm 1.2 \times 10^{10}$ to $10 \pm 3.5 \times 10^{10}$ viruses $\mathrm{l}^{-1} \mathrm{~d}^{-1}$ using TFD and from $-3.9 \pm 1.6 \times$ $10^{10}$ to $25 \pm 10 \times 10^{10}$ viruses $\mathrm{l}^{-1} \mathrm{~d}^{-1}$ using vacuum diafiltration. These observations are within the range of previously reported VP estimates for near-shore coastal waters, e.g. between $2.8 \times 10^{9}$ and $43 \times$ $10^{10}$ viruses $\mathrm{l}^{-1} \mathrm{~d}^{-1}$ (Table 4 ; Steward et al. 1992b, Guixa-Boixereu et al. 1996, Noble \& Fuhrman 2000, Wilhelm et al. 2002, Poorvin et al. 2004), indicating that both methods produce reasonable estimates of VP. Most importantly, TFD demonstrated consistently higher bacterial recovery than vacuum diafiltration. Assuming equal viability of bacteria recovered by each procedure, TFD-based VP estimates are more accurate, because a larger proportion of the natural bacterial community is present during the experiment and a smaller conversion factor is needed to account for bacterial loss.

The TFD method, like other VP methods, relies on 3 basic assumptions (Table 1): (1) all viruses produced during the incubation period are from the lysis of bacteria already infected at the start of the 
experiment; (2) no new infections occur during the incubation time period; and (3) filtration does not affect community diversity or composition. The reduction of free viruses in water samples from 16 to $46 \%$ of ambient levels through TFD and the short incubation time greatly reduces the possibility of new viral infection during dilution experiments (Wilhelm et al. 2002). Steady increases in viral abundance throughout experimental incubations were not always observed in this study. Instead, 2 or more increases in viral abundance followed by decreases were observed in this study and in subsequent experiments using TFD. Explanations for this behavior of viral abundance within experimental incubations include the release of viruses with different latent periods during the experiments or absorption, new infection, and cell death from viruses released in early lysis events. The complication of new infection-lysis events within the experimental incubation can be overcome by calculating VP rates using varying incubation times (Noble \& Fuhrman 2000). With this approach we found that significant changes in VP estimates occurred once when the incubation time was cut from $12 \mathrm{~h}$ to 6 or $9 \mathrm{~h}$. A shortened incubation time with more frequent sampling could resolve this dilemma of VP from new infection events.

The dilution approaches used in this study allow the estimation of net VP. Thus, virulent and temperate VP are indistinguishable from one another with this method. However, both contribute to VP in natural environments, and, assuming the incidence of lysogenic induction is not altered by diafiltration, it is accurately included in the dilution approach's estimation of net VP. Implementation of the TFD protocol is technically easier and less time-consuming than vacuum diafiltration for the highly productive and turbid waters of the Chesapeake and Delaware Bays. Despite attempts to alleviate the problem, filter clogging always resulted in greater manipulation of samples during vacuum diafiltration than during TFD. Excessive manipulation increases the risk of sample contamination, loss of bacterial viability from additional exposure to air and filtration hardware, and possibly induction of temperate bacteriophages. Lengthened exposure to temperatures and light levels different from ambient conditions may also induce changes in the bacterial community that could affect subsequent VP estimates. Therefore, TFD with less sample manipulation is again the preferred method.

Both diafiltration methods showed lower actual viral dilution and bacterial recovery efficiency than theoretically possible. However, subsequent VP estimates were independent of bacterial recovery or viral dilution efficiency at the start of an experiment (data not shown). Thus, the percentage of bacterial recovery or viral dilution did not affect the VP estimation. Interestingly, in only 1 of the experiments did VP estimates based on the different protocols agree on whether the viral population was declining or increasing (Table 2).

Several possible explanations exist for the observed discrepancies in VP trends between the 2 methodologies. First, the difference in starting time of the experiments may have captured diurnal changes in VP. However, the 1 to $1.5 \mathrm{~h}$ delay in starting incubations of vacuum-diafiltered water was probably not long enough to introduce diurnal changes in the balance between VP and decay (Winter et al. 2004a). A difference in the composition, activity, or viability of the bacterial community remaining after each diafiltration procedure may also have caused the observed differences. For example, discrepancies in VP estimates between the 2 methods could result from differences in the number or types of infected bacteria lost during diafiltration. Vacuum diafiltration, with its lower bacterial recovery efficiency and longer handling times, may be more susceptible to these effects than TFD. Finally, inconsistent filter and slide preparation within an experiment could lead to erroneous VLP enumeration (Noble \& Fuhrman 1998, Chen et al. 2001). This would affect VP estimates and could cause the observed discrepancies between the diafiltration methods. Enumeration of replicate filters from a given sample would resolve this problem.

Although negative VP estimates occur at the stations with the highest viral abundance, no significant relationship was found between VP and ambient or $t_{0}$ viral or bacterial abundance or VBR for either method or the combined data set. Therefore, negative VP estimates were not due to changing viral or host abundances or VBRs in ambient water samples or incubations. The lack of correlation between VP estimates and viral abundance, bacterial abundance, or VBR agrees with previous findings (Choi et al. 2003). However, this disagrees with other observed correlations between VP and bacterial abundance (Steward et al. 1992b, Weinbauer et al. 2003b), indicating that other environmental factors, such as temperature, light, or ambient nutrient levels, may influence VP. The negative VP estimates observed in this study may be due to variations in abiotic factors, such as DOM and nutrient levels, between sample locations or between sample filtration processes. The vacuum method is more likely to result in artificially altered DOM concentrations in incubations because of the increased potential for cell lysis when using impact filters during diafiltration.

Experimentation with the filter size, flow rate, and flushing volume used for TFD showed that the bacterial recovery and viral dilution efficiencies of this 
method varied little over the range of conditions tested. Ultimately, the $0.22 \mu \mathrm{m}$ filter and larger, 4 -fold flushing volume were chosen as optimal conditions for presumably more representative recovery of the natural bacterial community. The medium flow rate $\left(40 \mathrm{ml} \mathrm{min}{ }^{-1}\right)$ was selected as the most advantageous for its faster processing time and higher bacterial recovery.

Since these experiments were performed, the storage of seawater samples at $4^{\circ} \mathrm{C}$ with the addition of an aldehyde preservative has been shown to cause significant declines in viral abundance, as assessed via epifluorescence microscopy (Brussaard 2004, Wen et al. 2004). In our study, sample degradation in the TFD and vacuum experiments occurred. Some $t_{1}(3 \mathrm{~h})$ and $t_{3}(9 \mathrm{~h})$ time point samples were enumerated approximately 5 mo after the other time points. The $t_{0}$ time points for all VP experiments involved were recounted on the same day as the $t_{1}$ and $t_{3}$ samples. Average loss of VLPs per day due to sample degradation for each experiment was calculated as the difference in the $t_{0}$ counts divided by the time in days that elapsed between assessment dates. Subsequently, average loss rate in VLPs per day was used to correct VLP counts in the $t_{1}$ and $t_{3}$ water samples. Removal of the $t_{1}$ and $t_{3}$ counts from these experiments marginally increased VP estimates for 3 experiments and made the VP rate of the vacuum-based experiment at Stn DB 14 more negative. None of the changes in VP estimates due to the exclusion of these data points significantly altered VP estimates ( $p>0.05)$.

Corrections to all viral abundances for the VP experiments were also made using the decay models presented in Wen et al. (2004). VP estimates were then recalculated based on revised viral abundances and compared to original VP estimates. The VP estimates for 5 experiments increased after re-calculation, while 3 decreased. However, for 7 out of 8 experiments no statistically significant differences were found between the original and re-calculated VP estimates ( $p>0.05)$. For all experiments, results of comparisons of VP estimates between TFD and vacuum diafiltration methods remained unchanged ( $p>0.05)$. Thus, the VP values presented here have not been corrected for viral degradation except at the time points mentioned above. Both the TFD and vacuum diafiltration samples for each of these experiments were subjected to the same preservation conditions and demonstrated similar degradation rates. Therefore, assessments of differences in VP estimates were not affected by storage conditions. Determinations of bacterial recovery or viral loss with each method were not affected by storage conditions, as these statistics were based on the ambient water and $t_{0}$ counts made shortly after sample collection.

\section{Bacterioplankton mortality and biogeochemical impacts of viral lysis}

VP estimates from this study and other coastal environments (Bratbak et al. 1992, Steward et al. 1992b, Fuhrman \& Noble 1995, Guixa-Boixereu et al. 1996, Noble \& Fuhrman 2000, Wilhelm et al. 2002, Poorvin et al. 2004) are higher than VP rates in more oligotrophic environments and freshwater lakes (Table 4; Weinbauer et al. 1993, 2003a, Mathias et al. 1995, Steward et al. 1996, Noble \& Fuhrman 2000, Hwang \& Cho 2002, Middelboe et al. 2002, Bettarel et al. 2004, Winter et al. 2004a). These observed differences in production rates may be due to the variety of methods used. However, it appears that none of the methods consistently produces higher or lower estimates. Further measurement of VP and related variables at a variety of locations using consistent methodology and sample preservation is needed to identify potential correlation between the nutrient and DOM status of an environment and VP.

Compared to the findings of this study, similar proportions of bacterial standing stock were lost to viral infection off the coast of British Columbia (Wilhelm et al. 2002), in Tampa Bay (Jiang \& Paul 1994), and in Antarctic waters (Guixa-Boixereu et al. 2002). Levels of VMM found in this study were high compared to a variety of other environments (Table 4; Weinbauer et al. 1993, Guixa-Boixereu et al. 1996, Steward et al. 1996, Wilhelm et al. 1998, Noble \& Fuhrman 2000, Hwang \& Cho 2002, Middelboe et al. 2002, Choi et al. 2003, Bettarel et al. 2004). Despite falling within the range of previously reported values, observations of $>100 \%$ of BP and standing stock lost to viral lysis appear unrealistic for the Chesapeake and Delaware Bay systems, which typically demonstrate high rates of BP. High VMM, in excess of bacterial standing stock, has been observed in other studies (Weinbauer et al. 1995, 2002, GuixaBoixereu et al. 2002, Wilhelm et al. 2002), but low rates of VMM have also been reported for eutrophic lakes (Bettarel et al. 2004). Thus, VMM may also vary with location and ambient conditions. VP estimates used to calculate VMM represent instantaneous snapshots of community dynamics that, when averaged with other observations taken over a longer time period, might yield numbers more closely correlated to BP. Furthermore, VMM estimates in this study are based on an assumed viral burst size of 50 viruses released per cell lysed. Doubling the burst size used in the calculations to 100 would decrease all but 1 of the percentages of BP consumed to values $<100 \%$ (Table 3). Future work is needed to determine an accurate average bacteriophage burst size for the Chesapeake Bay.

Dissolved organic carbon (DOC) release estimates from the Chesapeake and Delaware Bays exceed or 
fall within those reported in previous VP studies from a range of marine ecosystems (Table 4). Bratbak et al. (1992) estimated a higher rate of DOC release than in this study; however, these authors concede that such high DOC flux was an overestimation. Our increased estimates are probably due to the high level of VMM observed in this study, which is used to calculate DOC release. Paradoxically, the March experiment at Stn CB 804 showed the highest levels of VMM and C release, but the lowest level of BP lost to lysis (Table 3). Together, these results indicate that the impacts of viruses on bacterial populations and BP may vary with changes in environmental conditions occurring over annual cycles, geographic location, and depth. As VP varies over space and time, viral lysis may have varying impacts on the quantity of $\mathrm{C}$ and other cell constituents added to the DOM pool.

In conclusion, the TFD method yields a marked improvement in bacterial recovery efficiency over the previously described vacuum diafiltration method for estimation of VP by dilution. As a result, the magnitude of a key conversion factor, the inverse of bacterial recovery, is reduced and the resultant VP estimates are closer to actual production values. Compared to the vacuum method, the shorter processing time and reduced sample manipulation in the TFD method decrease the possibility of the diafiltration process altering VP estimates. The large amounts of $\mathrm{C}$ released and BP lost to viral lysis and the high rates of VP observed in the Chesapeake and Delaware Bays in this study offer tantalizing insights into the influence of viruses on bacterioplankton and DOM production in estuaries. Further investigations are necessary to determine if VP and associated parameters of burst size, VMM, and percent $\mathrm{BP}$ lost to lysis fluctuate seasonally or vary spatially with changing DOM concentrations and abiotic factors.

Acknowledgements. We thank the crew of the RV 'Cape Henlopen' for assistance with sample collection and J. M. Winget for technical assistance. This research was supported by the National Science Foundation through a pre-doctoral fellowship to D.M.W. and Grant MCB-0132070 to K.E.W.

\section{LITERATURE CITED}

Bergh O, Borsheim KY, Bratbak G, Heldal M (1989) High abundance of viruses found in aquatic environments. Nature 340:467-468

Bettarel Y, Sime-Ngando T, Amblard C, Dolan J (2004) Viral activity in two contrasting lake ecosystems. Appl Environ Microbiol 70:2941-2951

Binder B (1999) Reconsidering the relationship between virally induced bacterial mortality and frequency of infected cells. Aquat Microb Ecol 18:207-215

Bratbak G, Heldal M, Thingstad TF, Riemann B, Haslund OH (1992) Incorporation of viruses into the budget of microbial
C-transfer-a first approach. Mar Ecol Prog Ser 83:273-280

Brussaard CPD (2004) Optimization of procedures for counting viruses by flow cytometry. Appl Environ Microbiol 70: 1506-1513

Chen F, Suttle CA, Short SM (1996) Genetic diversity in marine algal virus communities as revealed by sequence analysis of DNA polymerase genes. Appl Environ Microbiol 62:2869-2874

Chen F, Lu J, Binder BJ, Liu YC, Hodson RH (2001) Application of digital image analysis and flow cytometry to enumerate marine viruses stained with SYBR Gold. Appl Environ Microbiol 67:539-545

Choi DH, Hwang CY, Cho C (2003) Comparison of virus- and bacterivory-induced bacterial mortality in the eutrophic Masan Bay, Korea. Aquat Microb Ecol 30:117-125

Cottrell MT, Suttle CA (1991) Wide-spread occurrence and clonal variation in viruses which cause lysis of a cosmopolitan eukaryotic marine phytoplankter, Micromonas pusilla. Mar Ecol Prog Ser 78:1-9

Fuhrman JA (1992) Bacterioplankton roles in cycling of organic matter: the microbial food web. In: Falkowski PG, Woodhead AD (eds) Primary productivity and biogeochemical cycles in the sea. Plenum Press, New York, p 361-383

Fuhrman JA (1999) Marine viruses and their biogeochemical and ecological effects. Nature 399:541-548

Fuhrman JA, Noble RT (1995) Viruses and protists cause similar bacterial mortality in coastal seawater. Limnol Oceanogr 40:1236-1242

Fuhrman JA, Schwalbach M (2003) Viral influence on aquatic bacterial communities. Biol Bull (Woods Hole) 204:192-195

Gobler CJ, Hutchins DA, Fisher NS, Cosper EM, SanudoWilhelmy SA (1997) Release and bioavailability of C, N, P, $\mathrm{Se}$, and Fe following viral lysis of a marine chrysophyte. Limnol Oceanogr 42:1492-1504

Guixa-Boixereu N, Calderon-Paz JI, Heldal M, Bratbak G, Pedros-Alio C (1996) Viral lysis and bacterivory as prokaryotic loss factors along a salinity gradient. Aquat Microb Ecol 11:215-227

Guixa-Boixereu N, Lysnes K, Pedros-Alio C (1999) Viral lysis and bacterivory during a phytoplankton bloom in a coastal water microcosm. Appl Environ Microbiol 65:1949-1958

Guixa-Boixereu N, Vaque D, Gasol JM, Sanchez-Camara J, Pedros-Alio C (2002) Viral distribution and activity in Antarctic waters. Deep-Sea Res II 49:827-845

Heldal M, Bratbak G (1991) Production and decay of viruses in aquatic environments. Mar Ecol Prog Ser 72:205-212

Helton RR, Cottrell MT, Kirchman DL, Wommack KE (2005) Evaluation of incubation-based methods for estimating virioplankton production in estuaries. Aquat Microb Ecol 41:209-219

Hwang CY, Cho BC (2002) Virus-infected bacteria in oligotrophic open waters of the East Sea, Korea. Aquat Microb Ecol 30:1-9

Jiang SC, Paul JH (1994) Seasonal and diel abundance of viruses and occurrence of lysogeny/bacteriocinogeny in the marine environment. Mar Ecol Prog Ser 104:163-172

Kepner RL, Wharton RA, Suttle CA (1998) Viruses in Antarctic lakes. Limnol Oceanogr 43:1754-1761

Kirchman D, Knees E, Hodson R (1985) Leucine incorporation and its potential as a measure of protein-synthesis by bacteria in natural aquatic systems. Appl Environ Microbiol 49:599-607

Lu J, Chen F, Hodson RH (2001) Distribution, isolation, host specificity, and diversity of cyanophages infecting marine Synechococcus spp. in river estuaries. Appl Environ Microbiol 67:3285-3290 
Mathias CB, Kirschner AKT, Velimirov B (1995) Seasonal variations of virus abundance and viral control of the bacterial production in a backwater system of the Danube River. Appl Environ Microbiol 61:3734-3740

Middelboe M, Nielsen TG, Bjornsen PK (2002) Viral and bacterial production in the North Water: in situ measurements, batch-culture experiments and characterization and distribution of a virus-host system. Deep-Sea Res II 49: 5063-5079

Murray AG, Jackson GA (1992) Viral dynamics: a model of the effects of size, shape, motion, and abundance of single-celled planktonic organisms and other particles. Mar Ecol Prog Ser 89:103-116

Noble RT, Fuhrman JA (1998) Use of SYBR Green I for rapid epifluorescence counts of marine viruses and bacteria. Aquat Microb Ecol 14:113-118

Noble RT, Fuhrman JA (2000) Rapid virus production and removal as measured with fluorescently labeled viruses as tracers. Appl Environ Microbiol 66:3790-3797

Noble RT, Steward GF (2001) Estimating viral proliferation in aquatic samples. In: Paul JH (ed) Methods in microbiology, Vol 30. Plenum Press, New York, p 67-82

Poorvin L, Rinta-Kanto JM, Hutchins DA, Wilhelm SW (2004) Viral release of iron and its bioavailability to marine plankton. Limnol Oceanogr 49:1734-1741

Proctor LM, Fuhrman JA (1991) Roles of viral infection in organic particle flux. Mar Ecol Prog Ser 69:133-142

Proctor LM, Okubo A, Fuhrman JA (1993) Calibrating estimates of phage-induced mortality in marine bacteriaultrastructural studies of marine bacteriophage development from one-step growth experiments. Microb Ecol 25: 161-182

Smith DC, Azam F (1992) A simple, economical method for measuring bacterial protein synthesis rates in seawater using (super) ${ }^{3} \mathrm{H}$-leucine. Mar Microb Food Webs 6: 107-114

Steward GF, Wikner J, Smith DC, Cochlan WP, Azam F (1992a) Estimation of virus production in the sea. I. Method development. Mar Microb Food Webs 6:57-78

Steward GF, Wikner J, Cochlan WP, Smith DC, Azam F (1992b) Estimation of virus production in the sea. II. Field results. Mar Microb Food Webs 6:79-90

Steward GF, Smith DC, Azam F (1996) Abundance and production of bacteria and viruses in the Bering and Chukchi Seas. Mar Ecol Prog Ser 131:287-300

Suttle CA, Chan AM (1993) Marine cyanophages infecting oceanic and coastal strains of Synechococcus-abundance, morphology, cross-infectivity and growth-characteristics. Mar Ecol Prog Ser 92:99-109

Suttle CA, Chan AM (1994) Dynamics and distribution of cyanophages and their effect on marine Synechococcus spp. Appl Environ Microbiol 60:3167-3174

Thingstad TF, Lignell R (1997) Theoretical models for the control of bacterial growth rate, abundance, diversity and carbon demand. Aquat Microb Ecol 13:19-27

Tuomi P, Kuuppo P (1999) Viral lysis and grazing loss of bacteria in nutrient- and carbon-manipulated brackish water enclosures. J Plankton Res 21:923-937

van Hannen EJ, Zwart G, van Agterveld MP, Gons HJ, Ebert J, Laanbroek HJ (1999) Changes in bacterial and eukaryotic community structure after mass lysis of filamentous cyanobacteria associated with viruses. Appl Environ

Editorial responsibility: Gunnar Bratbak, Oslo, Norway
Microbiol 65:795-801

Wang K, Chen F (2004) Genetic diversity and population dynamics of cyanophage communities in the Chesapeake Bay. Aquat Microb Ecol 34:105-116

Waterbury JB, Valois FW (1993) Resistance to co-occurring phages enables marine Synechococcus communities to coexist with cyanophages abundant in seawater. Appl Environ Microbiol 59:3393-3399

Weinbauer MG, Höfle MG (1998) Significance of viral lysis and flagellate grazing as factors controlling bacterioplankton production in a eutrophic lake. Appl Environ Microbiol 64:431-438

Weinbauer MG, Peduzzi P (1995) Effect of virus-rich high molecular weight concentrates of seawater on the dynamics of dissolved amino acids and carbohydrates. Mar Ecol Prog Ser 127:245-253

Weinbauer MG, Fuks D, Peduzzi P (1993) Distribution of viruses and dissolved DNA along a coastal trophic gradient in the northern Adriatic Sea. Appl Environ Microbiol 59:4074-4082

Weinbauer MG, Fuks D, Puskaric S, Peduzzi P (1995) Diel, seasonal, and depth-related variability of viruses and dissolved DNA in the northern Adriatic Sea. Microb Ecol 30: 25-41

Weinbauer MG, Winter C, Höfle MG (2002) Reconsidering transmission electron microscopy based estimates of viral infection of bacterio-plankton using conversion factors derived from natural communities. Aquat Microb Ecol 27: 103-110

Weinbauer MG, Brettar I, Höfle MG (2003a) Lysogeny and virus-induced mortality of bacterioplankton in surface, deep, and anoxic marine waters. Limnol Oceanogr 48: $1457-1465$

Weinbauer MG, Christaki U, Nedoma A, Šimek K (2003b) Comparing the effects of resource enrichment and grazing on viral production in a meso-eutrophic reservoir. Aquat Microb Ecol 31:137-144

Wen K, Ortmann AC, Suttle CA (2004) Accurate estimation of viral abundance by epifluorescence microscopy. Appl Environ Microbiol 70:3862-3867

Wilhelm SW, Suttle CA (1999) Viruses and nutrient cycles in the sea. BioScience 49:781-788

Wilhelm SW, Weinbauer MG, Suttle CA, Jeffrey WH (1998) The role of sunlight in the removal and repair of viruses in the sea. Limnol Oceanogr 43:586-592

Wilhelm SW, Brigden SM, Suttle CA (2002) A dilution technique for the direct measurement of viral production: a comparison in stratified and tidally mixed coastal waters. Microb Ecol 43:168-173

Winter C, Herndl GJ, Weinbauer MG (2004a) Diel cycles in viral infection of bacterioplankton in the North Sea. Aquat Microb Ecol 35:207-216

Winter C, Smit A, Herndl GJ, Weinbauer MG (2004b) Impact of virioplankton on archaeal and bacterial community richness as assessed in seawater batch cultures. Appl Environ Microbiol 70:804-813

Wommack KE, Colwell RR (2000) Virioplankton: viruses in aquatic ecosystems. Microbiol Mol Biol Rev 64:69-114

Wommack KE, Ravel J, Hill RT, Chun J, Colwell RR (1999) Population dynamics of Chesapeake Bay virioplankton: total-community analysis by pulsed-field gel electrophoresis. Appl Environ Microbiol 65:231-240

Submitted: March 23, 2005; Accepted: October 4, 2005

Proofs received from author(s): December 13, 2005 